\title{
蝶形骨洞に再発したグロームス腫瘍例
}

\author{
松原 真美・中川 隆之・坂本 達則・伊藤 壽一
}

\section{A Case of Recurrent Glomus Tumor Arising in the Sphenoid Sinus}

\author{
Mami Matsubara, Takayuki Nakagawa, Tatsunori Sakamoto and Juichi Ito \\ (Graduate School of Medicine, Kyoto University)
}

\begin{abstract}
Glomus tumor, also known as glomangioma, is a specialized arteriovenous anastomosis usually found in the skin of the extremities. This rare tumor is seldom located in the nasal cavity or paranasal sinuses. Here in we present a case of recurrent glomus tumor in the sphenoid sinus, which is the first reported case to our knowledge. We successfully resected the tumor using an endonasal, endoscopic approach after embolization of the feeding arteries. Histopathologic examination revealed the recurrence of the glomus tumor. The control of intraoperative bleeding is crucial for the complete excision of this tumor through an endonasal, endoscopic approach.
\end{abstract}

Key words : sphenoid sinus, glomangioma, endoscopic approach, embolization

はじめに

グロームス腫瘍は末梢動脈吻合部の特殊型であるグ ロームス小体より発生する比較的まれな腫瘍で，多くは 四肢末梢に発生し，耳鼻咽喉科領域，とくに鼻副鼻腔に 発生することはきわめてまれとされている，鼻副鼻腔原 発のグロームス腫瘍例はこれまでの報告では国内外合わ せて 24 例認めるが, 再発例に関する報告は 2 例のみであ る. 治療は完全摘出とされているが，本腫瘍は血管に富 む腫瘍であり，外科的に摘出するにあたっては出血のコ ントロールが重要な問題となる. 今回われわれは,グロー ムス腫瘍の蝶形骨洞での再発例を経験し, 内視鏡下鼻内 手術にて摘出しえたので報告する.

\section{症例}

患者: 51 歳, 男性.

主訴：鼻出血.

既往歴：49 歳 C 型肝炎.

家族歷：特記すべきことなし.

現病歴：1998 年鼻閉を主訴に近医を受診し, 左蝶形骨
洞から後鼻孔に至る血管腫との診断で腫瘍摘出術を施行 された. 内視鏡下に YAG レーザーを用いて摘出した際 $1000 \mathrm{ml}$ の出血があり, 腫瘍全摘で止血しえた. 病理組 織診断にて, グロームス腫瘍と診断. 以後再発を認めて いなかったが, 2007 年 5 月に動脈性の鼻出血を認め, 精 査の結果, 左蝶形骨洞での腫瘍再発が疑われたため手術 目的で当科紹介となった.

現症 : 鼻腔ファイバーにて左蝶形骨洞前壁内側に暗赤 色の腫瘤を認めた (図 $1 \mathrm{~A})$. その他鼻内に異常所見を認 めなかった。

検查所見 : 末梢血液検查, 凝固検査に異常を認めず, 血清生化学検查は $\mathrm{HCV}$ 抗体陽性を認めるほかに異常を 認めなかった。

画像所見: 単純 CT にて, 両側上顎洞, 左蝶形骨洞前 壁に軟部陰影を認めた（図 1B). MRI では，CT 所見に 合致する両側上顎洞および左蝶形骨洞に軟部陰影を認め た. 左蝶形骨洞内の陰影は, $\mathrm{T} 1$ 強調像で低信号, T2 強 調像で内部不均一な高信号を示した. 両側上顎洞内の陰 影は蝶形骨洞内の病変とは異なり, $\mathrm{T} 1$ 強調像で高信号を 


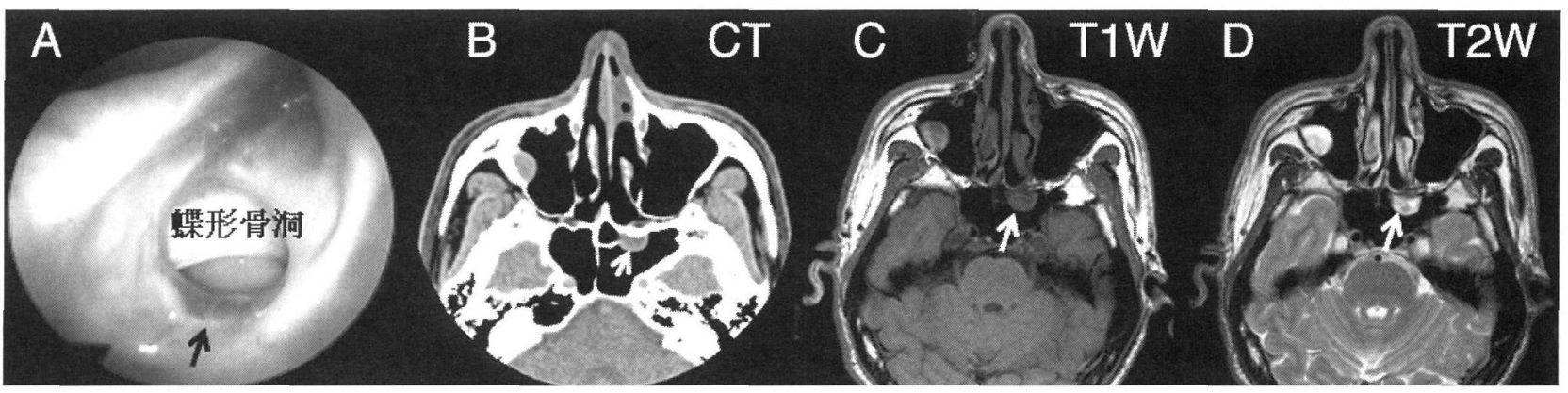

図 1 画像所見

A：内視鏡所見. 蝶形骨洞前壁内側に暗赤色の粘膜変化を認める (矢印).

B : CT 所見. 両側上顎洞内, 左蝶形骨洞前壁に軟部陰影を認める (矢印).

C : MRI T1 強調像（T1W）所見. 両側上靧洞内に高信号を示す軟部陰影を認める. 左蝶形骨洞内に低信号を示す軟部陰影を認 める (矢印).

D : MRI T2 強調像（T2W）所見. 左蝶形骨洞内に内部不均一な高信号軟部陰影を認める（矢印）.

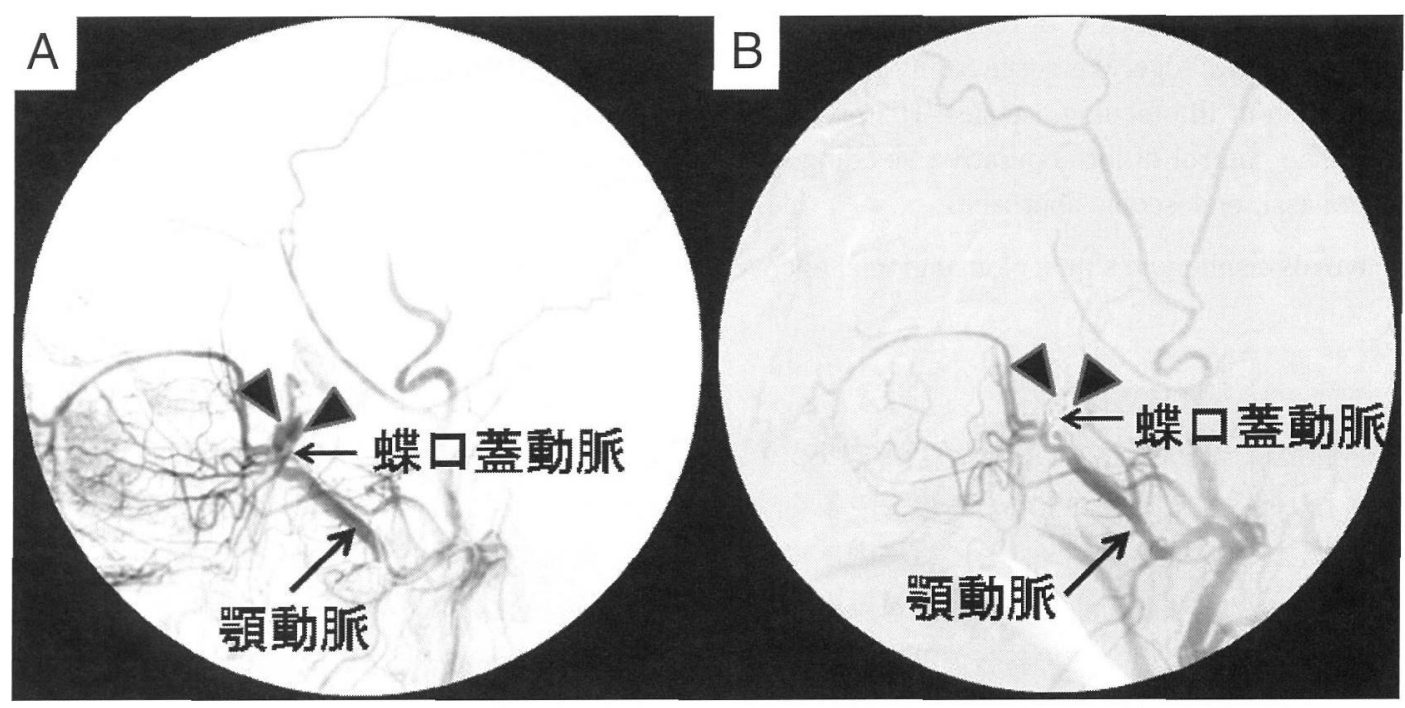

図 2 血管造影

A：塞栓術前所見. 矢頭は腫瘍血管の位置を示す。

B：塞栓術後所見. 矢頭は腫瘍濃染像の消失を示す.

示した (図 $1 \mathrm{C}, \mathrm{D}$ ).

治療：左蝶形骨洞グロームス腫瘍再発と診断し，腫瘍 血管塞栓術ならびに鼻内内視鏡下手術を予定した。腫愓 血管塞栓術に先行して施行した血管造影検査にて栄養血 管は蝶口蓋動脈であることが同定された。顎動脈から蝶 口蓋動脈への分岐部でユイルによる塞栓, さらに polyvinil alcohol 粒子（PVA 粒子）による血管床の塞栓を 追加し，腫瘍濃染像の消失を確認した（図 2).

翌日に全身麻酔下で鼻内視鏡下に腫瘍摘出術を行っ た。蝶篩陷门から左蝶形骨洞前壁にかけて骨膜弁を挙上
し，蝶形骨前壁を露出した。鋤骨部分切除，蝶形骨洞前 壁部分切除を行い, 蝶形骨洞内への広い交通を形成した. この際，左蝶形骨洞の正中部から操作し，骨壁をドリル で十分に薄くした後に削除，蝶形骨洞粘膜の温存に留意 した。腫瘍を含む蝶形骨洞粘膜を広く剥離挙上し，次い で上顎洞膜様部後方で蝶口盖動脈を露出し，バイポーラ で凝固切断した。この際, 塞栓部位を切除しないように, 血管の切除は可能な限り末梢側で行った。蝶口盍動脈の 末梢部分を含める形で骨粘膜弁を挙上し，蝶形骨洞自然 口に向かって剥離を進めた. 中鼻甲介下端部切離を行い, 

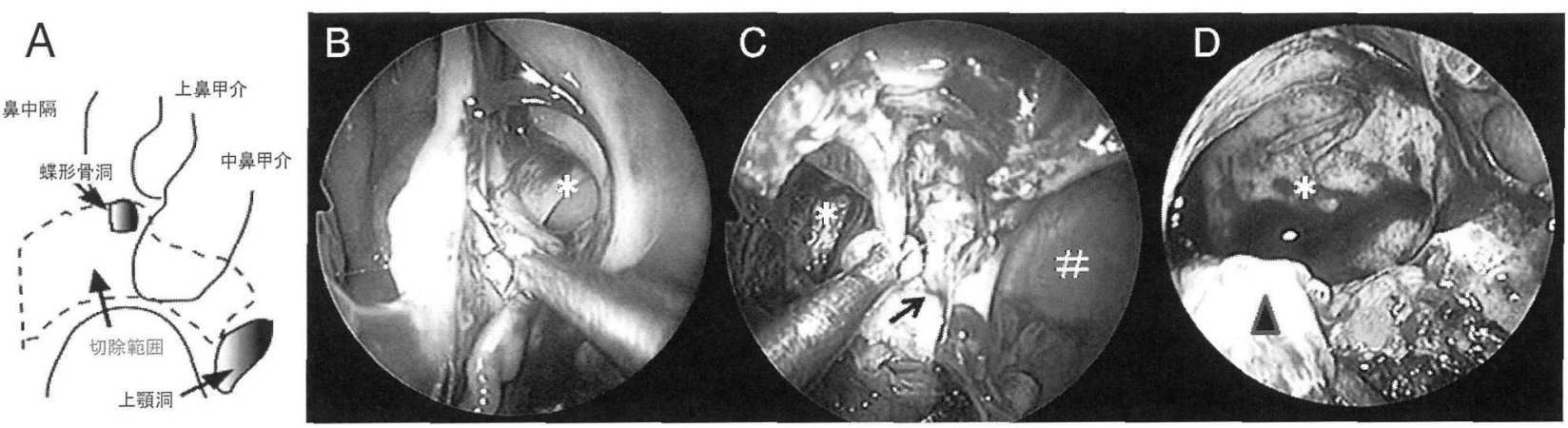

図 3 手術所見

A : 手術所見シェーマ. 点線は切除範围を示す.

B：鼻中隔側汃ら蝶形骨洞（*）に向加て骨粘膜弁学上。

C : 蝶口蓋孔 (矢印) 加ら蝶形骨洞自然口（）に向加て骨粘膜弁を挙上. 蝶口蓋動脈を塞栓部位より末梢側で凝固切断. 井は上顎洞を示す。

D：蝶口蓋動脈末梢側を切除側に含め（矢頭）と一塊に切除。*は蝶形骨洞を示す。

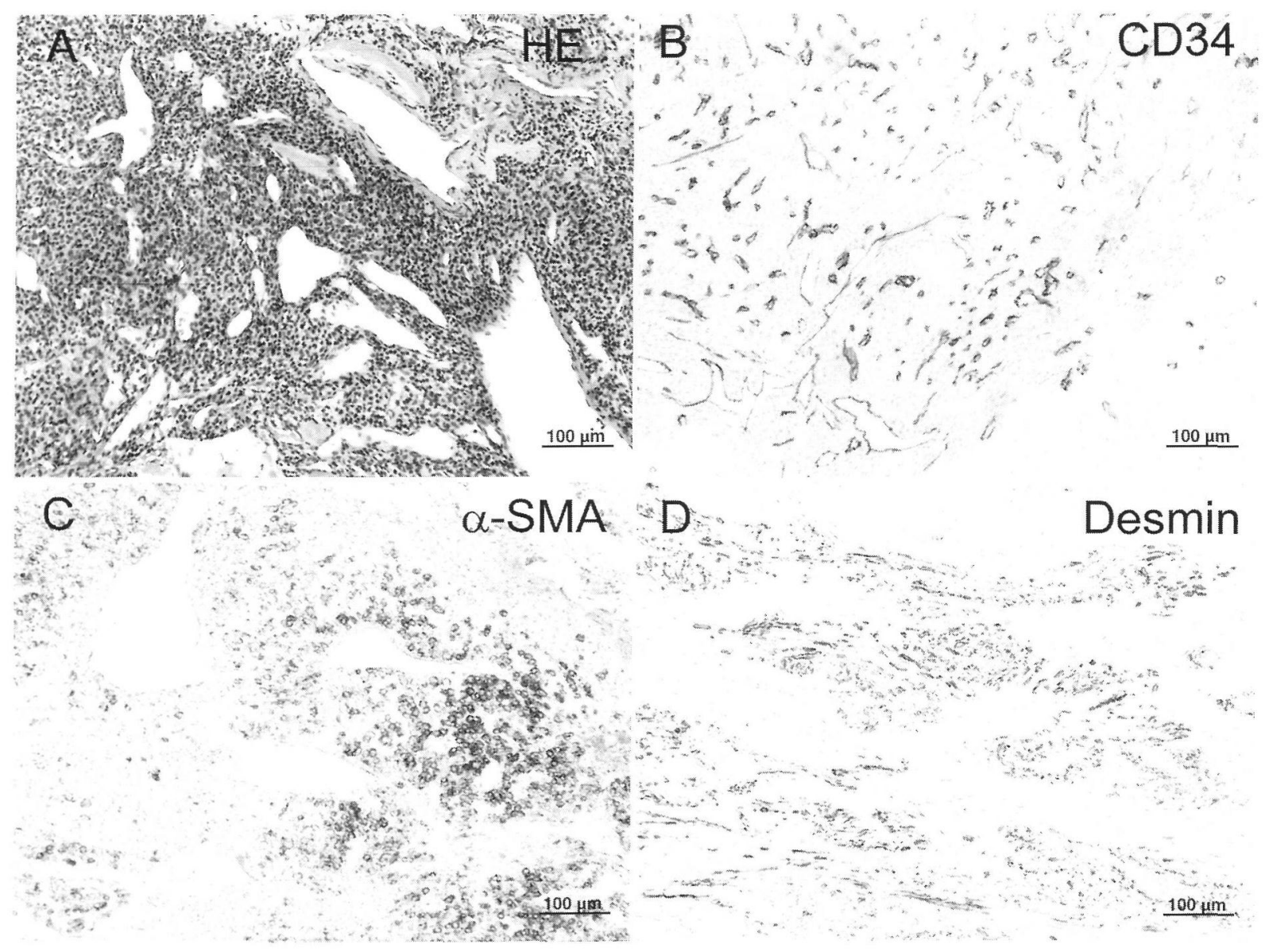

図 4 病理所見

$\mathrm{A}$ : HE 染色 $(\times 10)$ 粘膜直下で小型円形核と淡好酸性の細胞質を有する細胞がシート状に增殖し, 血管周皮様のパターンを示す.

B：免役染色 CD34（×10）血管内皮細胞で発現を認め, 腫瘍細胞では発現を認めない.

C : 危疫染色 $\alpha$-SMA $(\times 10)$ 腫愓細胞の一部で発現を認める.

D : 免疫染色 Desmin $(\times 10)$ 腫瘍細胞に発現を認める. 
骨粘膜弁，中鼻甲介下端，蝶形骨洞粘膜を一塊として切 除した（図 3).出血は $80 \mathrm{ml}$ で，創部にサージセル留置 のみを行い，タンポンの充填は行わなかった．上顎洞内 の病変は貯留霊胞と判断し経過観察とした. 術後出血認 めず，術後 3 日目に退院となった。

病理組織：HE 染色では粘膜直下に小型円形核と淡好 酸性の細胞質を有する腫瘍巣を認めた。細血管の介在が 随所にみられ，血管周皮様のパターンがみられた（図 $4 \mathrm{~A})$ ．個々の細胞は異型に乏しく，核分裂や壊死像は認 めなかった. 免疫組織化学染色では血管内皮のマーカー である CD34 では血管内皮で発現を認め, 腫瘍細胞では 発現を認めなかった (図 4 B). 一部の腫愓で平滑筋のマー カーである $\alpha$-smooth muscle actin（以下 $\alpha$-SMA とする) の発現を認め (図 4C), Desmin の発現も認めた (図4D). 以上より,グロームス腫瘍と診断された。

\section{考察}

グロームス腫瘍は良性の腫瘍で，グロームス小体の過
形成または過誤腫といわれている，正常のグロームス小 体は動静脈吻合部に存在し，体温の調節を担っている. グロームス腫瘍は比較的まれな腫瘍で軟部組織の腫瘍中 $1.6 \%$ という報告がある。そのうち鼻・副鼻腔の腫瘍は $0.4 \%$ と報告されている1). 起源となるグロームス小体の みられる四肢，とくに手指の爪床下に好発するがグロー ムス小体がほとんど存在しないか，まったく存在しない 部位にも発生しうる。まれな部位としては喉頭，気管， 胃，大腿などが報告されている2)。一般的に若年女性の 指の爪床に好発し，数 $\mathrm{mm}$ 径の小さな赤紫色の病巣を作 り，しばしば発作性の激痛をきたす．組織学的には好酸 性の明るい細胞質と卵円核を有する均一な円形細胞が細 小血管周囲に増殖し，血管腔の全部，あるいは一部を囲 む像を呈する．細胞は上皮様の配列を示し，ときに腫瘍 細胞は平滑筋への移行像を示す．また免疫組織化学的所 見も確定診断に有効であり，一般的にグロームス腫瘍細 胞はビメンチン陽性, muscle specific actin 陽性，ケラチ ン陰性, S-100 蛋白蛋陰性, epithelial membrane antigen

表 1 鼻副鼻腔グロームス腫瘍報告例（24 例）

\begin{tabular}{|c|c|c|c|c|c|}
\hline 報告者 & 報告年 & 年齢 & 性別 & 部位 & 症状 \\
\hline Pantazopoulos ${ }^{4)}$ & 1965 & 45 & 女 & 下鼻甲介 & 鼻閉, 疼痛, 鼻出血 \\
\hline $\operatorname{DeBord}^{5)}$ & 1972 & 33 & 女 & 後鼻孔 & 鼻閉 \\
\hline $\mathrm{Fu} \bigsqcup^{6)}$ & 1974 & 71 & 女 & 鼻中隔 & 無症状 \\
\hline Fleury $ら^{7)}$ & 1979 & 24 & 男 & 鼻中隔 & 鼻閉 \\
\hline Potter $5^{8)}$ & 1984 & 81 & 女 & 鼻中隔 & 無症状 \\
\hline 安江ら9) & 1985 & 39 & 女 & 鼻尖 & 有痛性結節 \\
\hline 田中 ${ }^{10)}$ & 1985 & 72 & 女 & 中鼻洞 & 鼻出血 \\
\hline Morais $\bigsqcup^{11)}$ & 1986 & 66 & 男 & 外鼻孔 & 無症状 \\
\hline Alarcos $5^{12)}$ & 1992 & 55 & 男 & 篩骨洞 & 鼻閉 \\
\hline 小泉ら ${ }^{13)}$ & 1992 & 58 & 男 & 鼻前庭 & 疼痛 \\
\hline Hayes $\bigsqcup^{14)}$ & 1993 & 32 & 女 & 外鼻孔 & 鼻閉 \\
\hline 樋口ら & 1993 & 55 & 男 & 右鼻腔, 前頭洞, 篩骨洞 & 鼻閉 \\
\hline Arens $\bigsqcup^{16)}$ & 1993 & 40 & 男 & 下鼻甲介 & 鼻出血 \\
\hline Shimono $ら^{17)}$ & 1998 & 55 & 男 & 篩骨洞 & 鼻閉 \\
\hline Cullen $ら^{18)}$ & 1999 & 50 & 女 & 下鼻甲介 & 鼻出血 \\
\hline Nakagawa $\bigsqcup^{1)}$ & 2000 & 42 & 男 & 蝶形骨洞 & 鼻閉 \\
\hline Shek $ら^{19)}$ & 2001 & 41 & 女 & 鼻中隔 & 鼻閉 \\
\hline Ahmed $ら^{20)}$ & 2003 & 56 & 女 & 鼻中隔 & 鼻出血 \\
\hline \multirow[t]{2}{*}{$\mathrm{Li} ら^{3)}$} & 2003 & 69 & 女 & 左鼻腔 & 鼻汁 \\
\hline & 2003 & 81 & 女 & 右鼻腔 & 鼻出血 \\
\hline Keelawat $ら^{21)}$ & 2004 & 66 & 女 & 鼻中隔 & 無症状 \\
\hline 本田ら ${ }^{22)}$ & 2004 & 45 & 女 & 右鼻腔 & 鼻閉, 鼻出血 \\
\hline Gaut $ら^{23)}$ & 2005 & 87 & 女 & 左鼻腔 & 鼻閉, 鼻出血 \\
\hline 大野ら ${ }^{24)}$ & 2006 & 58 & 男 & 左鼻腔 & 鼻出血 \\
\hline
\end{tabular}


（以下 EMA）陰性, 第VIII因子関連抗原陰性であると報告 されている3 . 本症例は $\alpha$-SMA 陽性, Desmin 陽性, CD34 陰性であり, 従来の報告に一致する所見であった.

鼻・副鼻腔発生のグロームス腫瘍はまれであり，われ われの調べた限りでは現在までに自験例も含め 24 例の報 告がある (表 1) 1334) 24). これら 24 例についてみると 性比は男: 女 $=3: 5$ と女性に多く, 年齢は $24 \sim 87$ 歳と 多岐にわたる. とくに発生部位として, 副鼻腔はまれで あり, 24 例中 4 例のみが副鼻腔由来であり, 蝶形骨洞由 来の報告は本例のみである. 症状は鼻閉, 鼻出血, 疼痛 などであるが，無症状のことも多く特異的な症状は認め られない。

グロームス腫愓は, 通常良性腫瘍とみなされ局所の完 全切除で根治可能といわれている.これまでの報告では, 自験例を含め再発例の報告は 3 例認められている. 再発 を認めた Hayes らの報告14) では, 初回手術後 14 年間で 6 回の局所再発を認め, 切除術を施行している.これは 病理診断で浸潤傾向を認めたこと, また 32 歳と若い女性 の顔面の腫瘍であり，切除範囲の美容上の問題から限定 されたためと推察される. 自験例では, 前回の手術で内 視鏡下に YAGレーザーで腫瘍を全摘したが, 手術開始直 後より大量の出血を認め,一部残存したことが予想され, 良好な視野の確保が重要であると考えられる。

今回の手術に際しては, 鼻内視鏡下での切除に先行し て, 腫瘍血管塞栓術を行った。このため, 術中の出血は ほとんど認められず，良好な視野での完全摘出が可能で あった．また，タンポン充填を行わなかったが，術後出 血も認めていない，本例のような血管性腫瘍や多量の出 血が予想される線維性血管腫などの内視鏡下手術を行う 際には，十分な視野を確保するために術前に塞栓術を行 い, 出血を可能な限り減らすことが重要となる，術前の 塞栓術と術中のバイポーラによる蝶口蓋動脈凝固切断の 両方を行うことは確実な止血の点から有用と考える。 た, 本例では広く骨粘膜弁を栄養血管を含める形で挙上 し, 腫瘍と一塊にして切除することに留意し, 再発防止 を企図した。 今後, 詳細な経過観察を行う予定である.

\section{まとめ}

1. 蝶形骨洞に再発したグロームス腫瘍の 1 例を経験し た.

2. 術前の血管塞栓術施行により, 術中出血はほとんど なく, 良好な視野で内視鏡下鼻内手術にての完全摘出が
可能であった.

3. 多量の出血が予想される鼻副鼻腔腫瘍の内視鏡下 手術に際しては，血管塞栓術などの術前処置がきわめて 重要であると考えられた.

本論文の要旨は第 99 回日本耳鼻咽喉科学会京滋地方部会 （2008年 3 月 8 日，京都府）にて発表した.

\section{参考文献}

1) Nakagawa $T$, Takashima $T$, Tomiyama $K$, et al. : Glomangioma in the nasal cavity and paranasal sinuses. ORL J Otorhinolaryngol Relat Spec 62:164 166, 2000.

2) Lee WT, Murthy SC, Gildea TR, et al. : First case of laryngeal glomangiomyoma. Laryngoscope $115: 2038 \sim 2040,2005$.

3) Li Xo, Hisaoka M, Morio T, et al. : Intranasal pericytic tumors (glomus tumor and sinonasal hemangiopericytoma-like tumor): Report of two cases with review of the literature. Pathol Int $53: 303 \sim 308,2003$.

4) Pantazopoulos PE : Glomus tumor (Glomangioma) of the nasal cavity. Arch Otolaryngol 81: 83 86, 1965.

5) DeBord BA : Unusual presentations in otolaryngology. Surg Clin North Am $52: 473 \sim 483,1972$.

6) Fu YS and Perizin KH : Non-epithelial tumors of the nasal cavity, paranasal sinuses, and nasopharynx: A clinicopathologic study. I. General features and vascular tumors. Cancer 33 : $1275 \sim 1288,1974$.

7) Fleury P, Bassett JM, Compère JF, et al. : Rare tumors of the septum. 8 reported cases. Ann Otolaryngol Chir Cervicofac $96: 767 \sim 779,1979$.

8) Potter AJ Jr, Khatib G and Peppard SB : Intranasal glomus tumor. Arch Otolaryngol $110: 755 \sim 756,1984$.

9）安江厚子, 中島幹夫, 石垣 優, 他: 鼻尖部に生じたグロ ム又腫瘍. 皮虚臨床 $27: 750 \sim 751,1985$.

10）田中 弘：固有鼻腔に発生したグロムス腫瘍の 1 例. 日耳 鼻会報 $88 ： 706,1985$.

11) Morais D, Rodríguez J, Velasco MC, et al. : Glomangioma or glomus tumor of the nasal vestibulum. An otorrinolaringol Ibero Am $13: 471 \sim 479,1986$.

12) Alarcos Llorach A, Matesanz Sanz A, Alarcos Tamayo E, et al. : A glomus tumor of the nasal fossa and ethmoid sinus. Acta Otorrinolaringol Esp $43: 291 \sim 295,1992$.

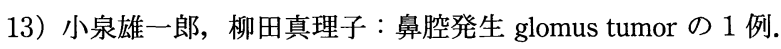
日皮会誌 $102: 209,1992$.

14) Hayes MM, Van der Westhuizen $N$ and Holden GP : Aggressive glomus tumor of the nasal region. Report of a case with multiple local recurrences. Arch pathol Lab Med $117: 649 \sim$ 652, 1993.

15）樋口香里, 和田義正, 三牧三郎, 他 : 副鼻腔グロームスの 
1 例. 耳鼻・頭頸外科 $68: 111 \sim 116,1996$.

16) Arens $C$, Dreyer T, Eistert B, et al. : Glomangioma of the nasal cavity. Case report and literature review. ORL J Otorhinolaryngol Relat Spec $59: 179 \sim 181,1997$.

17) Shimono T, Hayakawa K, Yamaoka T, et al. : Case report: Glomus tumor of the nasal cavity and paranasal sinuses. Neuroradiology $40: 527 \sim 529,1998$.

18) Cullen RD and Hanna EY : Intranasal glomangioma. Am J Otolaryngol $21: 402 \sim 404,2000$.

19) Shek TW and Hui $Y$ : Glomangiomyoma of the nasal cavity. Am J Otolaryngol $22: 282 \sim 285,2001$.

20) Ahmed A, Sheehan AL and Dugar J : Intranasal glomangioma. Rhinology $41: 58 \sim 60,2003$.

21) Keelawat $S$, Hirunwiwatkul $P$ and Thanakit $V:$ Recurrent epistaxis from an intranasal glomus tumor: the 22nd case report. J Med Assoc Thai $87: 442 \sim 445,2004$.

22）本田耕平, 三原国昭, 花田巨志, 他 : 鼻腔グロームス腫瘍 の 1 例. 頭頸部外 $14: 261 \sim 265,2004$.

23) Gaut AW, Jay AP, Robinson RA, et al. : Invasive glomus tumor of the nasal cavity. Am J Otolaryngol $26: 207 \sim 209,2005$.

24）大野雅昭, 野村智幸, 花沢秀行, 他 : 固有鼻腔より発生し たグロームス腫瘍の 1 例. 日鼻科会誌 $45: 355,2006$.

原稿受付：平成20年 4 月 2 日 原稿採択 : 平成 20 年 5 月 8 日 別刷請求先 : 松原真美

T632-8552 天理市三島町200

天理よろづ相談所病院耳鼻咽喉科 